\title{
Green Spectrophotometric Estimation of Minor Concentrations of Methyldopa and Terbutaline Sulphate in Pure Forms and Tablets Using Polyvinylpyrrolidone- Capped Silver Nanoparticles
}

\author{
Magda Mohamed Ayad, Mervat Mohamed Hosny, Youstina Mekhail Metias \\ Department of Analytical Chemistry, Faculty of pharmacy, Zagazig University, Zagazig, Egypt.
}

Corresponding authors. E-mail: dr_youstina@ymail.com

Received: Nov. 30, 2020; Accepted: Jul. I, 202I; Published: Aug. 16, 2021

Citation: Magda Mohamed Ayad, Mervat Mohamed Hosny, and Youstina Mekhail Metias, Green Spectrophotometric Estimation of Minor Concentrations of Methyldopa and Terbutaline Sulphate in Pure Forms and Tablets Using Polyvinylpyrrolidone-Capped Silver Nanoparticles. Nano Biomed. Eng., 202I, I3(3): 240-248.

DOI: $10.5101 /$ nbe.v13i3.p240-248.

\begin{abstract}
Sensitive and simple colorimetric method was developed for determination of methyldopa and terbutaline sulphate in pure and pharmaceutical dosage forms. The method was based on reduction of silver ions by the cited drugs in basic medium at $90{ }^{\circ} \mathrm{C}$ to silver nanoparticles in the presence of stabilizing agent as polyvinylpyrrolidone. The formed silver nanoparticles were distinguished by UV-Vis absorption spectroscopy indicating the characteristic surface plasmon resonance which can be also observed as intense yellow color solution. The plasmon absorbance of the silver nanoparticles was measured at $410 \mathrm{~nm}$ for quantitative estimation of methyldopa and terbutaline sulphate over the range of $80-480$ and $40-600 \mathrm{ng} / \mathrm{mL}$ respectively. Limit of detection was obtained as $26,13 \mathrm{ng} / \mathrm{mL}$ for methyldopa and terbutaline sulphate respectively. The eco-friendly developed method could be successfully applied to the pharmaceutical formulations with studying the interference of different excipients.
\end{abstract}

Keywords: Methyldopa, Terbutaline sulphate, Silver nanoparticles, Surface plasmon resonance, Colorimetry

\section{Introduction}

Methyldopa (MD) is alpha2-adrenergic receptor agonist of (2S)-2-amino-3-(3,4-dihydroxyphenyl)-2methylpropanoic acid [1]. MD is broadly indicated for management of hypertension, preferably for hypertension in pregnancy and this effect is mainly owing to its action on the CNS [2]. Several analytical methods have been developed for estimation of MD including official titrimetric methods [1,3], spectrophotometric determinations in pharmaceutical formulations [4-6] and in presence of other drugs $[7,8]$. HPLC with fluorescence [9], UV [10,11], electrochemical [12] detections and chiral HPLC for enantiomer separation [13] were applied. Electrochemical analysis $[14,15]$, and NMR spectroscopy [16] were also performed.

Terbutaline sulphate (TER) is an official [1,3], direct-acting sympathomimetic with a chemical definition of bis [(1RS)-1-(3,5-dihydroxyphenyl)2-[(1,1-dimethylethyl)amino]ethanol] sulphate [1]. TER has a selective action on beta ${ }_{2}$ agonists that relax 
bronchial smooth muscles producing bronchodilating effect used for obstructive pulmonary diseases. It is also indicated for premature labour because of decreasing uterine contractility [2]. From the literature survey, TER was estimated in different dosage forms using spectrophotometric [17-21], spectrofluorometric $[19,22]$ and electrochemical methods [23, 24]. Chromatographic analysis of TER were performed using HPTLC [25], gas chromatography [26] as well as HPLC [20] in biological fluids [27] and in combined dosage forms [28] with stability indicating studies [29]. The capillary zone electrophoresis method [30] was also applied for enantioseparation of TER enantiomers.

Metal nanoparticles, compared to their bulk atomic materials, have distinct physico-chemical properties owing to their large surface area and electronic properties utilized in potential applications of biotechnology and biomedical fields [31]. Noble metal nanoparticles of silver and gold have been the nanoparticles of interest in nanoscience and nanotechnology for many decades due to their stability, electric properties and strong optical absorption of electromagnetic radiation in the UV-Vis-NIR region. Upon the excitation of their conducting electrons with incident photon frequency, collective oscillations known as localized surface plasmon resonance (LSPR) will occur and result in extinction spectra. These extinction band depends on the size, shape and dielectric environment of nanoparticles [32]. Thus, silver nanoparticles (Ag-NPs) are considered one of the most vital nanomaterials possessing large degree of commercialization and now widely applicable in the field of surface plasmon resonance spectroscopy for determination of many pharmaceuticals.

Several spectrophotometric determinations using Ag-NPs were reported for catecholamines [33] reducing sugars [34] cannabinoids [35] etilefrine hydrochloride, fenoterol hydrobromide, salbutamol sulphate and estradiol valerate [36], L-cysteine [37] as well as cephalosporin antibiotics [38] and antiviral drugs [39]. Moreover, Ag-NPs were used as a fluorescence probe for assay exofenadine hydrochloride [40], as a nanocomposite modified electrode for voltammetric determination of clonazepam [41] and as a nanocatalyst to enhance chemiluminescence for nitrazepam [42] and isoniazid [43] investigations.

The present work measured peak intensity of surface plasmon resonance of Ag-NPs formed through reduction of $\mathrm{Ag}^{+}$ions by the studied drugs in the presence of polyvinylpyrrolidone (PVP) as a stabilizing agent in alkaline medium. The produced plasmon absorbance enabled highly sensitive and simple colorimetric assay of such commonly used drugs as MD and TER in the nano range, compared with other spectrophotometric methods [4-8, 17-21], without using any hazard chemicals.

\section{Experimental Instrumentation}

Single beam UV and visible spectrophotometer (JENWAY 6715, UK) equipped with $10 \mathrm{~mm}$ matched quartz cells was employed for all absorbance measurements.

Jenway 3510 digital $\mathrm{pH}$ meter and Wisd water bath (WiseBath ${ }^{\circledR}$, Germany) were used.

\section{Materials and Reagents}

Pure samples were kindly provided by their respective manufactures; methyldopa (supplied by Pharco Pharmaceuticals Inc., Alexandria, Egypt) and terbutaline sulfate (supplied by AB Draco, Lund, Sweden). Deionized, bi-distilled water and chemicals of analytical grade were used throughout this study. Silver nitrate ( $0.025 \mathrm{M}$ aqueous solution) from Morgan Speciality Chemicals Co., polyvinylpyrrolidone $(0.1$ or $0.14 \% \mathrm{w} / \mathrm{v}$ aqueous solution) from Sigma-Aldrich and sodium hydroxide (3 or $2 \mathrm{mM}$ aqueous solution) form El Nasr Chem. Co. were used for MD, TER respectively.

\section{Pharmaceutical preparations}

Aironyl $^{\circledR}$ tablets (Batch no: 0816314) and syrup (Batch no: 0918155) containing terbutaline sulfate; 2.5 mg per tablet and $1.5 \mathrm{mg}$ per $5 \mathrm{~mL}$ syrup (product of Sedico Pharmaceutical Co, 6 October city, Egypt).

Aldomet $^{\circledR}$ tablets (Batch no: 1810342) containing $500 \mathrm{mg}$ methyldopa and produced by Kahira pharm., Cairo, Egypt.

\section{Standard stock solutions}

Stock solutions $(1000 \mu \mathrm{g} / \mathrm{mL})$ were prepared by dissolving $100 \mathrm{mg}$ of the pure drug in $100 \mathrm{~mL}$ methanol and bi-distilled water for MD and TER respectively. Further dilution of each to $4 \mu \mathrm{g} / \mathrm{mL}$ was made using bi-distilled water.

\section{General procedure Construction of calibration graphs}

Aliquots of working solutions containing different 
concentrations of the cited drugs were transferred into $5 \mathrm{~mL}$ volumetric flask. Appropriate amounts of 0.025 M silver nitrate, $0.1 \%$ PVP, $3 \mathrm{mM} \mathrm{NaOH}$ for MD or 2 $\mathrm{mM} \mathrm{NaOH}, 0.14 \%$ PVP, $0.025 \mathrm{M}$ silver nitrate for TER were added respectively. Volumes were completed to $5 \mathrm{~mL}$ with bi-distilled water and then placed in a water bath at $90{ }^{\circ} \mathrm{C}$. After suitable heating time, absorbance was recorded at $410 \mathrm{~nm}$ against reagent blank (Table 1).

Table 1 Analytical performance data for spectrophotometric estimation MD and TER

\begin{tabular}{ccc}
\hline Parameter & MD & TER \\
\hline Linearity range $(\mu \mathrm{g} / \mathrm{mL})$ & $0.08-0.48$ & $0.04-0.6$ \\
$\lambda_{\max }(\mathrm{nm})$ & 410 & 410 \\
Volume of $0.025 \mathrm{M}$ Silver nitrate & $0.1 \mathrm{~mL}$ & $0.1 \mathrm{~mL}$ \\
Conc. and volume of PVP & $0.1 \%(1 \mathrm{~mL})$ & $0.14 \%(0.5 \mathrm{~mL})$ \\
Conc. and volume of $\mathrm{NaOH}$ & $3 \mathrm{mM}(0.7 \mathrm{~mL})$ & $2 \mathrm{mM}(1.5 \mathrm{~mL})$ \\
Temperature & $90{ }^{\circ} \mathrm{C}$ & $90{ }^{\circ} \mathrm{C}$ \\
Time of heating & $30 \mathrm{~min}$. & $15 \mathrm{~min}$. \\
Regression equation* & & \\
Intercept (a) & -0.028 & 0.0583 \\
Slope (b) & 2.1508 & 1.3604 \\
Correlation coefficient $\left(\mathrm{r}^{2}\right)$ & 0.9998 & 0.9999 \\
\hline
\end{tabular}

$* \mathrm{~A}=\mathrm{a}+\mathrm{bc}$

\section{Assay of pharmaceutical formulations}

For Aldomet ${ }^{\circledR}$ or Airony ${ }^{\circledR}$ tablets, a weighed amount of ten pulverized tablets equivalent to $100 \mathrm{mg}$ of $\mathrm{MD}$ or $10 \mathrm{mg}$ of TER was dissolved in $100 \mathrm{~mL}$ methanol or $10 \mathrm{~mL}$ bi-distilled water respectively. Solutions were well shaken and filtered then further diluted to $4 \mu \mathrm{g} / \mathrm{mL}$ with bi-distilled water.

For Aironyl syrup ${ }^{\circledast}, 5 \mathrm{~mL}$ of syrup and $5 \mathrm{~mL}$ of saturated $\mathrm{NaOH}$ were added into $60 \mathrm{~mL}$ separating funnel and extracted with $30 \mathrm{~mL}$ methylene chloride. The organic layer was evaporated till dryness and the residue was dissolved in $10 \mathrm{~mL}$ bi-distilled water then further diluted to $4 \mu \mathrm{g} / \mathrm{mL}$.

Procedures were completed as in general procedures using standard addition technique.

\section{Results and Discussion}

The proposed method relied on redox reaction between $\mathrm{AgNO}_{3}$ and the cited drugs which possess a phenolic group giving a reducing property in basic medium. Characteristic LSPR absorption peak observed at $410 \mathrm{~nm}$ which referred the formation of Ag-NPs and disappeared in reagent blank due to absence of the cited drugs (Fig. 1). These formed AgNPs at high temperature were effectively stabilized in the presence of capping agent as PVP and exhibited more intense absorption spectra with sharp plasmon

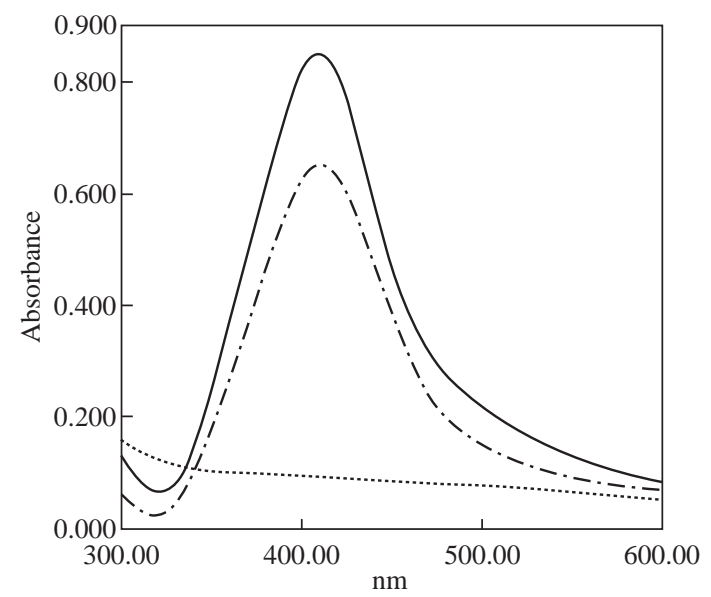

Fig. 1 Absorption spectra of the formed silver nanoparticles after heating $0.1,0.5 \mathrm{~mL}$ of $0.025 \mathrm{M} \mathrm{AgNO}_{3}$ with $0.32 \mu \mathrm{g} / \mathrm{mL}$ of MD $(-\cdot-)$ and $0.6 \mu \mathrm{g} / \mathrm{mL}$ of TER (-) respectively in the presence of PVP and $\mathrm{NaOH}$ under the optimum condition against blank $(\cdots)$.

resonance. The proposed method has the merits of being eco-friendly with high sensitivity attributed to the ability of the formed Ag-NPs to absorb UV light even in minor concentrations.

\section{Optimization of the reaction conditions}

The formation of Ag-NPS using chemical reduction method employs three essential components; precursors of metal, reductants, and stabilizing/capping agents [44]. The chemical conditions as concentrations of $\mathrm{AgNO}_{3}, \mathrm{PVP}$, and $\mathrm{NaOH}$, temperature as well as the reaction time were studied and optimized to obtain maximum silver plasmonic response.

\section{Effect of $\mathrm{NaOH}$ concentration and volume}

The redox reaction relied on reduction of $\mathrm{Ag}^{+}$to metallic silver nanoparticles (Ag-NPS) by the cited drugs. These drugs possess dihydroxyphenyl group that could undergo oxidation in basic medium via losing $\mathrm{H}^{+}$ to form phenolate anion which is more reducible [35] (Scheme 1). $\mathrm{NaOH}$ must be added to provide enough alkalinity as buffered condition wasn't enough to form silver nanoparticles. The increase in concentration of

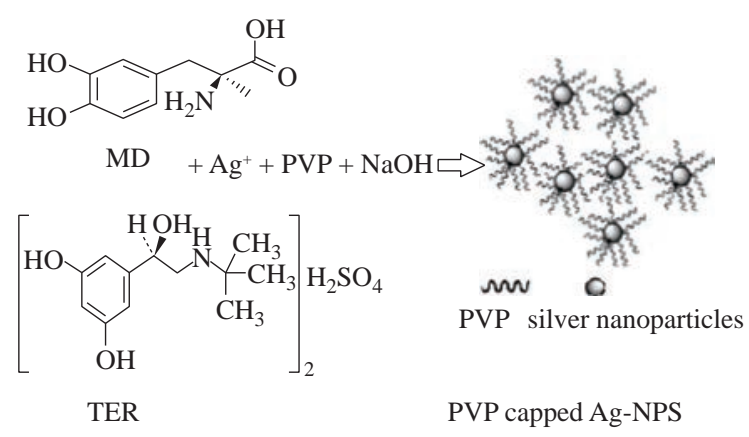

Scheme 1 Reduction of silver ion by the studied drugs. 
$\mathrm{NaOH}$ affected the plasmon intensity which raised up at the optimum concentration as shown in Fig. 2. At higher $\mathrm{NaOH}$ concentrations, the absorbance decreased which might be owing to formation of opaque $\mathrm{Ag}_{2} \mathrm{O}$ precipitate. Using $0.7 \mathrm{~mL}$ of $3 \mathrm{mM}$ and $1.5 \mathrm{~mL}$ of $2 \mathrm{mM} \mathrm{NaOH}$ were sufficient to obtain maximum absorbance of the formed silver nanoparticles for MD and TER respectively (Figs. 2 and 3).

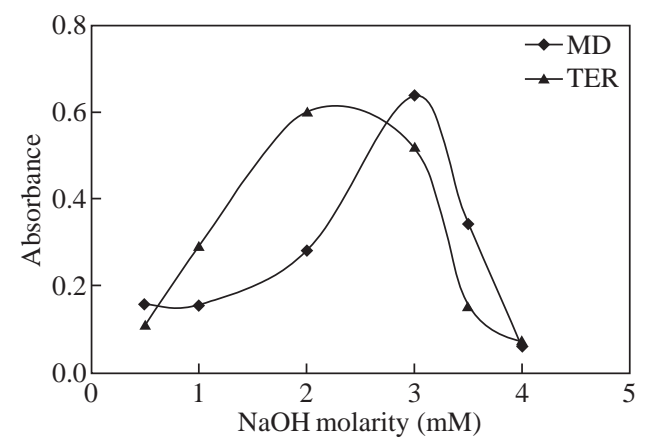

Fig. 2 Effect of $\mathrm{NaOH}$ conc. on absorption efficiency of the formed silver nanoparticles through reaction of $\mathrm{AgNO}_{3}$ with 0.32 $\mu \mathrm{g} / \mathrm{mL}$ MD and $0.4 \mu \mathrm{g} / \mathrm{mL}$ TER in the presence of PVP.

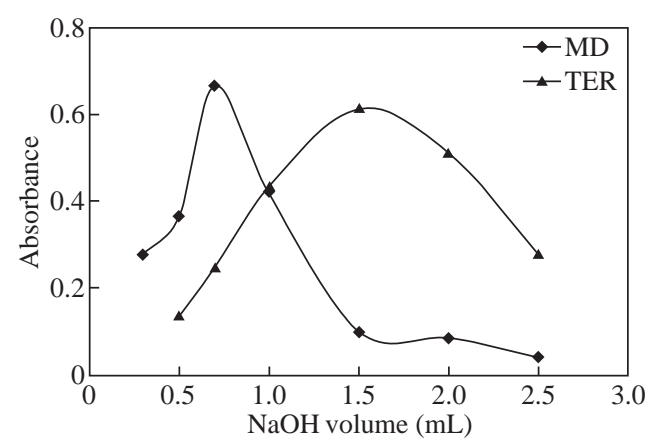

Fig. 3 Effect of 3 and $2 \mathrm{mM} \mathrm{NaOH}$ volume on absorption efficiency of the formed silver nanoparticles through reaction of $\mathrm{AgNO}_{3}$ with $0.32 \mu \mathrm{g} / \mathrm{mL} \mathrm{MD}$ and $0.4 \mu \mathrm{g} / \mathrm{mL}$ TER respectively in the presence of PVP.

\section{Effect of silver nitrate volume and concentra- tion}

It was found that $0.1 \mathrm{~mL}$ of $0.025 \mathrm{M}$ silver nitrate was convenient for maximum absorbance values for both drugs as shown in Figs. 4 and 5.

\section{Effect of stabilizer type and concentration}

Stabilization of metal nanoparticles is substantial during its synthesis to control particle growth and prevent aggregation. This process occurred through two basic mechanisms; electrostatic and steric stabilization [45]. Electrostatic stabilization is based on adsorbing the stabilizers, as sodium citrate, at the surface of AgNPS and forming electrical double layers thus causing columbic repulsion between the particles to prevent agglomeration.

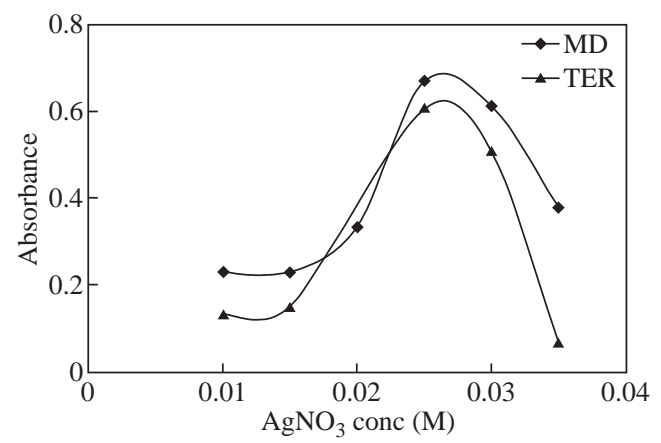

Fig. 4 Effect of $\mathrm{AgNO}_{3}$ conc. that reacted with $0.32 \mu \mathrm{g} / \mathrm{mL}$ MD and $0.4 \mu \mathrm{g} / \mathrm{mL}$ TER on absorption efficiency of the formed silver nanoparticles in the presence of PVP and $\mathrm{NaOH}$.

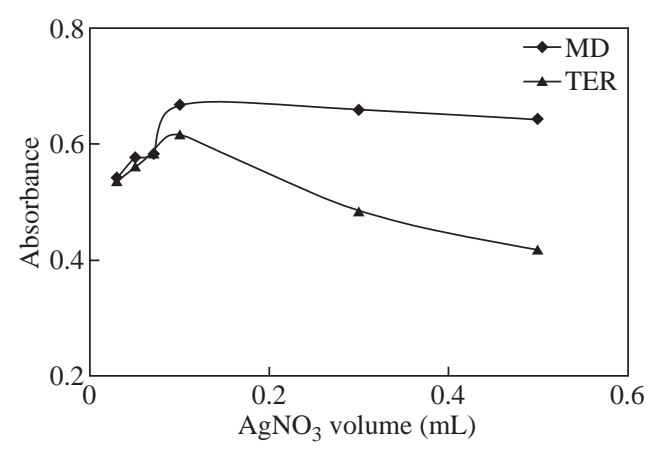

Fig. 5 Effect of $0.025 \mathrm{M} \mathrm{AgNO}_{3}$ volume reacting with 0.32 $\mu \mathrm{g} / \mathrm{mL} \mathrm{MD}$ and $0.4 \mu \mathrm{g} / \mathrm{mL}$ TER on absorption efficiency of the formed silver nanoparticles in the presence of PVP and $\mathrm{NaOH}$.

On the other hand, steric stabilizers such as PVP make protective shields on the surface of NPS by repulsion forces arise from its hydrophobic carbon chains which extend into solvents causing the steric hindrance effect [46]. In this study, PVP-capped NPS were used to prevent aggregation of Ag-NPS and gave higher absorbance and better linearity rather than those of citrate-stabilized Ag-NPS. Figs. 6 and 7 indicated that $1 \mathrm{~mL}$ of $0.1 \%$ and $0.5 \mathrm{~mL}$ of $0.14 \%(\mathrm{w} / \mathrm{v})$ PVP were the optimum for MD and TER respectively.

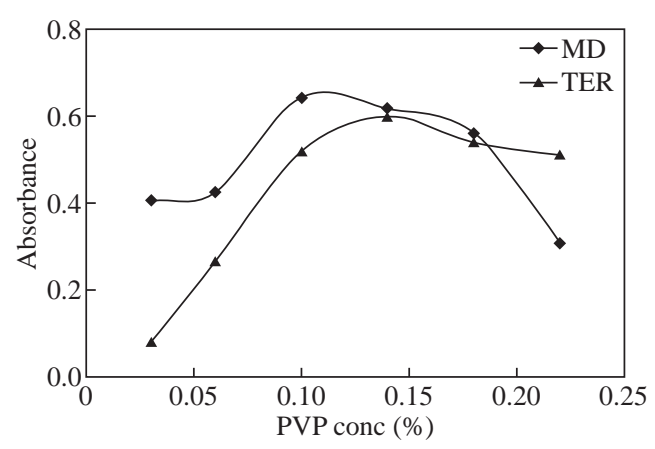

Fig. 6 Effect of PVP conc. on absorption efficiency of the formed silver nanoparticles through reaction of $0.025 \mathrm{M} \mathrm{AgNO}_{3}$ with $0.32 \mu \mathrm{g} / \mathrm{mL}$ MD and $0.4 \mu \mathrm{g} / \mathrm{mL}$ TER in the presence of $\mathrm{NaOH}$. 


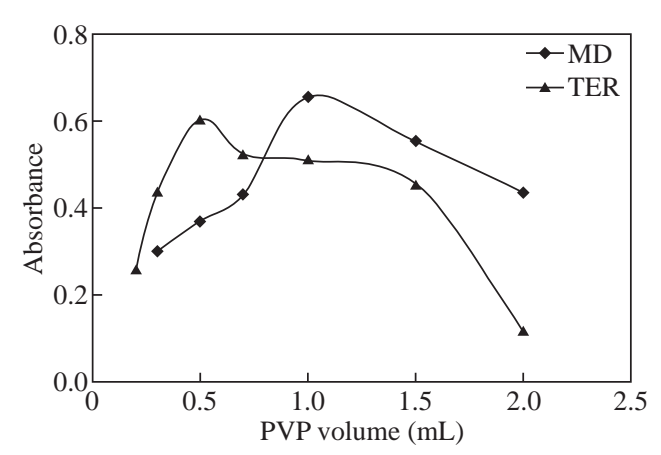

Fig. 7 Effect of 0.1, 0.14\% (w/v) PVP on absorption efficiency of the formed silver nanoparticles through reaction of $0.025 \mathrm{M}$ $\mathrm{AgNO}_{3}$ with $0.32 \mu \mathrm{g} / \mathrm{mL} \mathrm{MD}$ and $0.4 \mu \mathrm{g} / \mathrm{mL}$ TER respectively in the presence of $\mathrm{NaOH}$.

\section{Effect of temperature, time of heating and stability}

Absorption intensities were monitored at different temperatures for both drugs using a thermostatic water bath. At temperature higher than $60^{\circ} \mathrm{C}$, more intense and sharp peak appeared. Therefore, heating at $90{ }^{\circ} \mathrm{C}$ for 30 and $15 \mathrm{~min}$. were the optimal heating time for assay clear solution of the formed Ag-NPS for MD and TER respectively which would be stable up to one hour for measurements.

\section{Effect of order of addition}

The sequence of reactants addition was studied to maximize the absorption efficiency of the formed AgNPS by the cited drugs, Fig. 8 .

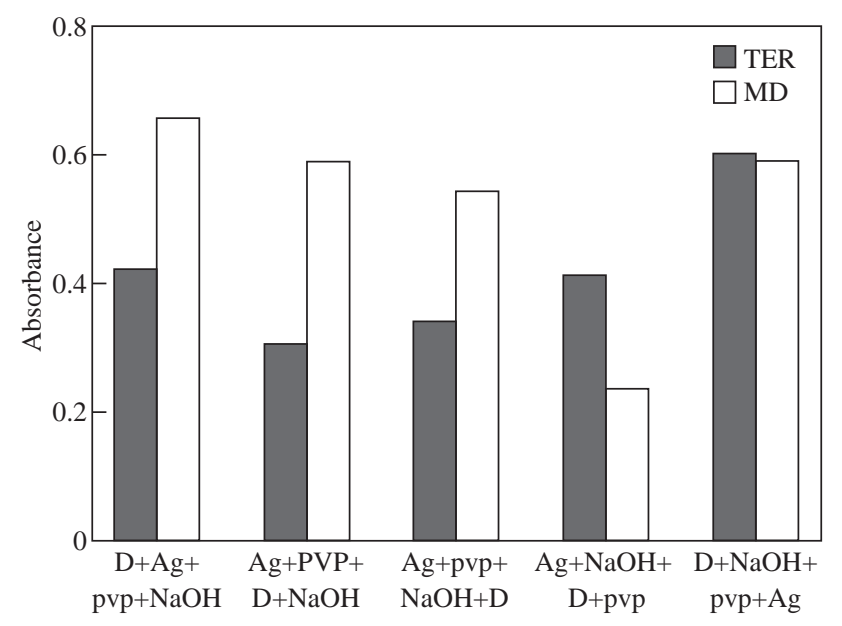

Fig. 8 Order of addition effect of $0.32 \mu \mathrm{g} / \mathrm{mL}$ MD and 0.4 $\mu \mathrm{g} / \mathrm{mL}$ TER with $0.025 \mathrm{M} \mathrm{AgNO}_{3}$ in the presence of PVP and $\mathrm{NaOH}$ on the absorbance of the formed silver nanoparticles.

\section{Method validation Linearity}

To obtain the calibration curves for estimation of MD and TER, absorbance of the formed Ag-NPS was plotted versus concentrations of the drugs. From statistical analysis of data, small intercepts and good correlation coefficients were attained over the working concentration ranges indicating good linearity, Tables 1 and 2 .

\section{Sensitivity}

According to the ICH guidelines [47], limits of detection and quantification (LOD \& LOQ) were calculated and listed in Table 2 using the following equations:

$\mathrm{LOD}=3.3$, and $\mathrm{LOQ}=10$,

where $\sigma=$ the standard deviation of the replicate blank responses, and $\mathrm{S}=$ the slope of the calibration curve.

\section{Accuracy}

The accuracy of the proposed method was examined by statistical comparison of the obtained results with those of the potentiometric official methods using nonaqueous titration and perchloric acid as a titrant[1]. It was found that no significant differences between the proposed methods and the official ones using Student's t-test and variance ratio $\mathrm{F}$-test at $95 \%$ confidence level, Table 3.

\section{Precision}

Intra-day and inter-day precisions of this method were evaluated by analyzing four different concentrations of each pure drug by triplicate determinations in the same day (intra-day) and in three different days (inter-day). The percentage relative standard deviation (RSD\%) and percentage relative error (Er\%) which was calculated using the following equation:

$\mathrm{Er} \%=[($ founded - added $) /$ added $] \times 100$,

and were evaluated and listed in Table 4 proving acceptable results for the suggested method.

\section{Selectivity}

For evaluation selectivity of the proposed method to assay the pharmaceutical dosage forms of the studied drugs, the interference effect of common excipients in the formulations was investigated. Known amounts of $\operatorname{MD}(0.48 \mu \mathrm{g} / \mathrm{mL})$ and TER $(0.6 \mu \mathrm{g} / \mathrm{mL})$ were analyzed under the optimum conditions in the presence of 0.4 $\mu \mathrm{g} / \mathrm{mL}$ of each excipient using the general procedures. Results in Table 5 showed no significant interference for MD while magnesium stearate and lactose interfered to some extent with TER. 
Table 2 Assay results for determination of MD and TER in pure forms using Ag-NPS

\begin{tabular}{|c|c|c|c|c|c|c|}
\hline \multirow{2}{*}{ Parameters } & \multicolumn{3}{|c|}{ MD } & \multicolumn{3}{|c|}{ TER } \\
\hline & Taken $(\mu \mathrm{g} / \mathrm{mL})$ & Found $(\mu \mathrm{g} / \mathrm{mL})$ & Recovery* (\%) & Taken $(\mu \mathrm{g} / \mathrm{mL})$ & Found $(\mu \mathrm{g} / \mathrm{mL})$ & Recovery * (\%) \\
\hline & 0.08 & 0.079 & 98.80 & 0.04 & 0.040 & 100.52 \\
\hline & 0.12 & 0.118 & 98.03 & 0.08 & 0.079 & 98.96 \\
\hline & 0.2 & 0.203 & 101.59 & 0.28 & 0.281 & 100.21 \\
\hline & 0.24 & 0.240 & 99.96 & 0.4 & 0.403 & 100.65 \\
\hline & 0.32 & 0.322 & 100.69 & 0.52 & 0.516 & 99.19 \\
\hline & 0.48 & 0.478 & 99.58 & 0.6 & 0.602 & 100.30 \\
\hline Mean \pm SD & & $99.77 \pm 1.282$ & & & $99.97 \pm 0.715$ & \\
\hline $\mathrm{n}$ & & 6 & & & 6 & \\
\hline RSD & & 1.285 & & & 0.715 & \\
\hline SE & & 0.484 & & & 0.292 & \\
\hline Variance & & 0.523 & & & 0.512 & \\
\hline Slope & & 2.1508 & & & 1.3604 & \\
\hline $\mathrm{LOD}(\mu \mathrm{g} / \mathrm{mL})$ & & 0.026 & & & 0.013 & \\
\hline LOQ $(\mu \mathrm{g} / \mathrm{mL})$ & & 0.078 & & & 0.040 & \\
\hline $\begin{array}{c}\mathrm{e}\left(\times 10^{5}\right) * * \\
\mathrm{~L} \cdot \mathrm{mol}^{-1} \cdot \mathrm{cm}^{-1}\end{array}$ & & 4.241 & & & 9.083 & \\
\hline
\end{tabular}

* Average of three different determinations

** Apparent Molar absorptivity was calculated on the basis of the molecular weight of the drug.

Table 3 Statistical analysis of results obtained by the proposed and the official methods

\begin{tabular}{|c|c|c|c|c|}
\hline \multirow{2}{*}{ Parameters } & \multicolumn{2}{|c|}{ MD } & \multicolumn{2}{|c|}{ TER } \\
\hline & Proposed method & BP official method $[1]^{* *}$ & Proposed method & BP official method [1]** \\
\hline Mean \pm SD & $99.77 \pm 1.282$ & $99.96 \pm 0.690$ & $99.97 \pm 0.715$ & $99.80 \pm 0.352$ \\
\hline Variance & 0.523 & 0.476 & 0.512 & 0.124 \\
\hline $\mathrm{n}$ & 6 & 3 & 6 & 3 \\
\hline Student t-test & $0.226(2.365)^{*}$ & -- & $0.387(2.365)^{*}$ & -- \\
\hline F-test & $3.454(5.79)^{*}$ & -- & $4.140(5.79)^{*}$ & -- \\
\hline
\end{tabular}

* The corresponding theoretical values for $\mathrm{t}$ and $\mathrm{F}$ tests at $\mathrm{p}=0.05$.

** Potentiometric official method for MD and TER.

Table 4 Precision data for determination of the studied drugs through formation of Ag-NPS

\begin{tabular}{|c|c|c|c|c|c|c|c|c|c|c|}
\hline & \multicolumn{5}{|c|}{ Intra-day } & \multicolumn{5}{|c|}{ Inter-day } \\
\hline & $\begin{array}{c}\text { Added } \\
(\mu \mathrm{g} / \mathrm{mL})\end{array}$ & $\begin{array}{l}\text { Found } \pm \text { SE } \\
(\mu \mathrm{g} / \mathrm{mL})\end{array}$ & Recover (\%) & RSD (\%) & $\operatorname{Er}(\%)$ & $\begin{array}{c}\text { Added } \\
(\mu \mathrm{g} / \mathrm{mL})\end{array}$ & $\begin{array}{l}\text { Found } \pm \text { SE } \\
(\mu \mathrm{g} / \mathrm{mL})\end{array}$ & Recovery (\%) & RSD (\%) & $\operatorname{Er}(\%)$ \\
\hline \multirow[t]{4}{*}{$\mathrm{MD}$} & 0.08 & $0.078 \pm 0.513$ & 98.03 & 0.906 & -1.97 & 0.08 & $0.081 \pm 1.025$ & 100.74 & 1.763 & 0.74 \\
\hline & 0.12 & $0.117 \pm 0.129$ & 97.90 & 0.229 & -2.1 & 0.12 & $0.119 \pm 1.103$ & 99.32 & 1.924 & -0.68 \\
\hline & 0.2 & $0.203 \pm 0.268$ & 101.59 & 0.458 & 1.59 & 0.2 & $0.202 \pm 0.205$ & 101.20 & 0.351 & 1.20 \\
\hline & 0.48 & $0.477 \pm 1.480$ & 99.38 & 0.258 & -0.62 & 0.48 & $0.482 \pm 0.563$ & 100.48 & 0.970 & 0.48 \\
\hline \multirow[t]{4}{*}{ TER } & 0.04 & $0.039 \pm 1.061$ & 98.68 & 1.862 & -1.32 & 0.04 & $0.039 \pm 1.225$ & 98.07 & 2.164 & -1.93 \\
\hline & 0.08 & $0.079 \pm 1.061$ & 98.96 & 1.857 & -1.04 & 0.08 & $0.079 \pm 0.810$ & 98.65 & 1.423 & -1.35 \\
\hline & 0.28 & $0.283 \pm 0.381$ & 100.91 & 0.655 & 0.91 & 0.28 & $0.278 \pm 1.050$ & 99.16 & 1.834 & -0.84 \\
\hline & 0.4 & $0.404 \pm 0.221$ & 101.08 & 0.378 & 1.08 & 0.4 & $0.400 \pm 1.003$ & 100.04 & 1.736 & 0.04 \\
\hline
\end{tabular}

Table 5 Analysis of the cited drugs by the proposed method in the presence of some common excipients

\begin{tabular}{|c|c|c|}
\hline \multirow{2}{*}{$\begin{array}{l}\text { Excipients added } \\
\quad(0.4 \mu \mathrm{g} / \mathrm{mL})\end{array}$} & \multicolumn{2}{|c|}{ Recovery (\%)* } \\
\hline & $\mathrm{MD}(0.48 \mu \mathrm{g} / \mathrm{mL})$ & $\operatorname{TER}(0.6 \mu \mathrm{g} / \mathrm{mL})$ \\
\hline Citric acid & 97.13 & -- \\
\hline Gum acacia & 100.66 & -- \\
\hline Magnesium stearate & 100.43 & 82.46 \\
\hline Starch & 99.96 & 97.34 \\
\hline Silica & 95.08 & -- \\
\hline Talc & 100.43 & -- \\
\hline Lactose & -- & 135.02 \\
\hline Povidone k30 & -- & 99.55 \\
\hline
\end{tabular}

* Mean of three determinations.

\section{Robustness and ruggedness}

The effect of slight variations in one parameter conditions while keeping all the others constant were studied to evaluate robustness of the proposed method performance. The studied variables were the volumes of $\mathrm{AgNO}_{3}( \pm 0.005 \mathrm{~mL}), \mathrm{PVP}( \pm 0.05 \mathrm{~mL}), \mathrm{NaOH}( \pm 0.05$ $\mathrm{mL})$ and heating time $( \pm 1 \mathrm{~min}$.) showing negligible influence on the results.

Ruggedness was also examined by performing the same procedures and assay of the studied drugs using 
Table 6 Robustness and ruggedness expressed as (recovery $\pm \%$ RSD) for the proposed method

\begin{tabular}{|c|c|c|c|c|c|c|c|c|c|c|}
\hline \multirow[b]{2}{*}{ Drugs } & \multicolumn{8}{|c|}{$\begin{array}{c}\text { Robustness } \\
\text { parameters altered }\end{array}$} & \multicolumn{2}{|c|}{$\begin{array}{c}\text { Ruggedness } \\
\text { inter-instruments }(n=2)\end{array}$} \\
\hline & $\begin{array}{l}\text { Taken } \\
(\mu \mathrm{g} / \mathrm{mL}\end{array}$ & PVP volume & $\begin{array}{c}\text { Taken } \\
(\mu \mathrm{g} / \mathrm{mL})\end{array}$ & $\mathrm{NaOH}$ volume & $\begin{array}{c}\text { Taken } \\
(\mu \mathrm{g} / \mathrm{mL})\end{array}$ & $\begin{array}{l}\text { Silver nitrate } \\
\text { volume }\end{array}$ & $\begin{array}{c}\text { Taken } \\
(\mu \mathrm{g} / \mathrm{mL})\end{array}$ & $\begin{array}{l}\text { Heating } \\
\text { time }\end{array}$ & $\begin{array}{c}\text { Taken } \\
(\mu \mathrm{g} / \mathrm{mL})\end{array}$ & $\begin{array}{l}\text { JENWAY6715UV/Vis. } \\
\text { ShimadzuUV-1201 }\end{array}$ \\
\hline MD & 0.12 & $101.13 \pm 1.014$ & 0.28 & $103.34 \pm 0.825$ & 0.12 & $100.48 \pm 1.460$ & 0.2 & $97.33 \pm 1.728$ & 0.2 & $96.24 \pm 1.025$ \\
\hline TER & 0.4 & $97.77 \pm 0.760$ & 0.28 & $102.31 \pm 1.603$ & 0.52 & $99.38 \pm 1.993$ & 0.08 & $100.18 \pm 1.909$ & 0.52 & $96.93 \pm 1.237$ \\
\hline
\end{tabular}

Table 7 Application of standard addition technique for determination of the cited drugs in the dosage forms using Ag-NPS

\begin{tabular}{|c|c|c|c|c|c|c|c|c|c|}
\hline \multirow{3}{*}{ Parameters } & \multicolumn{3}{|c|}{$\mathrm{MD}$} & \multicolumn{6}{|c|}{ TER } \\
\hline & \multicolumn{3}{|c|}{ Aldomet ${ }^{\circledR}$ tablets } & \multicolumn{3}{|c|}{ Aironyl ${ }^{\circledR}$ tablets } & \multicolumn{3}{|c|}{ Aironyl ${ }^{\circledR}$ syrup } \\
\hline & $\begin{array}{c}\text { Taken } \\
(\mu g / m L)\end{array}$ & $\begin{array}{c}\text { Added } \\
(\mu \mathrm{g} / \mathrm{mL})\end{array}$ & $\begin{array}{c}\text { Recovery* } \\
\text { (\%) }\end{array}$ & $\begin{array}{c}\text { Taken } \\
(\mu \mathrm{g} / \mathrm{mL})\end{array}$ & $\begin{array}{c}\text { Added } \\
(\mu \mathrm{g} / \mathrm{mL})\end{array}$ & $\begin{array}{c}\text { Recovery* } \\
\text { (\%) }\end{array}$ & $\begin{array}{c}\text { Taken } \\
(\mu \mathrm{g} / \mathrm{mL})\end{array}$ & $\begin{array}{c}\text { Added } \\
(\mu \mathrm{g} / \mathrm{mL})\end{array}$ & $\begin{array}{c}\text { Recovery* } \\
\text { (\%) }\end{array}$ \\
\hline & 0.08 & & 98.22 & 0.08 & & 98.04 & 0.08 & & 101.72 \\
\hline & & 0.12 & 98.03 & & 0.04 & 96.85 & & 0.04 & 102.36 \\
\hline & & 0.16 & 99.38 & & 0.28 & 97.32 & & 0.08 & 99.88 \\
\hline & & 0.24 & 97.64 & & 0.4 & 99.36 & & 0.2 & 102.07 \\
\hline & & 0.32 & 100.11 & & 0.44 & 98.52 & & 0.32 & 99.17 \\
\hline & & 0.4 & 99.96 & & 0.52 & 97.36 & & & \\
\hline Mean \pm SD & \multicolumn{3}{|c|}{$99.02 \pm 1.129$} & \multicolumn{3}{|c|}{$97.88 \pm 1.033$} & \multicolumn{3}{|c|}{$100.87 \pm 1.585$} \\
\hline $\mathrm{N}$ & \multicolumn{3}{|c|}{5} & \multicolumn{3}{|c|}{5} & \multicolumn{3}{|c|}{4} \\
\hline SE & \multicolumn{3}{|c|}{0.505} & \multicolumn{3}{|c|}{0.462} & \multicolumn{3}{|c|}{0.792} \\
\hline V & \multicolumn{3}{|c|}{1.276} & \multicolumn{3}{|c|}{1.067} & \multicolumn{3}{|c|}{2.511} \\
\hline
\end{tabular}

* Mean of three different experiments.

two different instruments. The obtained results were found to be reproducible and reliable (Table 6).

\section{Analytical applications}

Determination of the cited drugs in their commercial dosage forms (tablets and syrup) was successfully developed by the proposed method using standard addition technique. The satisfactory results were summarized in Table 7 showing the recoveries of target analytes and the standard deviations (SD).

\section{Conclusions}

The developed method was relied on measuring the formed silver nanoparticles using simple and cost effective spectrophotometry for sensitive assay of MD and TER. Upon heating the cited drugs with silver nitrate and PVP as stabilizer in alkaline medium, $\mathrm{Ag}^{+}$ions would be reduced to yellow in color AgNPS. Moreover, the proposed green procedures were validated for routine analysis of these drugs in pharmaceutical preparations with convenient precision, accuracy and no need for elaborate treatments.

\section{Conflict of Interests}

The authors declare that no competing interest exists.

\section{References}

[1] The British Pharmacopoeia, Her Majesty's Stationery Office, London, 2017: 258-259, 1025-1026.

[2] S.C. Sweetman, Martindale: the complete drug reference 38th ed., The Pharmaceutical Press, London; Chicago, 2014: 1431-1433, 1228-1229.

[3] The United States pharmacopeia and the national formulary (USP 36-NF 31), The United States Pharmacopeial Convention, Rockville, 2013: 4314-4315, 5318-5319.

[4] T. Aman, I. Ullah Khan, N. Aslam, et al., Spectrophotometric Determination of Methyldopa in Pure and Pharmaceutical Preparations. Analytical Letters, 1998, 31(6): 1007-1020.

[5] P.R.S. Ribeiro, J.A.G. Neto, L. Pezza, et al., Flowinjection spectrophotometric determination of methyldopa in pharmaceutical formulations. Talanta, 2005, 67(1): 240-244.

[6] A.A. Abdel-Monem, E.A. Bahgat, Spectrophotometric Microdetermination of Methyldopa and Etilefrine Hydrochloride using Copper (II)-Neocuproine Reagent in Pure Form and Pharmaceutical Formulations. Der Pharmacia Lettre, 2018, 10(8): 17-32. 
[7] M. Chamsaz, A. Safavi, J. Fadaee, Simultaneous kineticspectrophotometric determination of carbidopa, levodopa and methyldopa in the presence of citrate with the aid of multivariate calibration and artificial neural networks. Analytica chimica acta, 2007, 603(2): 140-146.

[8] R.L. Sawant, S.M. Mhaske, Analytical method development for simultaneous estimation of saxagliptin and methyldopa. Asian Journal of Pharmaceutical Research, 2014, 4(3): 134-140.

[9] G. Bahrami, A. Kiani, S. Mirzaeei, A rapid high performance liquid chromatographic determination of methyldopa in human serum with fluorescence detection and alumina extraction: Application to a bioequivalence study. Journal of Chromatography B, 2006, 832(2): 197201.

[10] S.F. Li, H.L. Wu, Y.J. Yu, et al., Quantitative analysis of levodopa, carbidopa and methyldopa in human plasma samples using HPLC-DAD combined with second-order calibration based on alternating trilinear decomposition algorithm. Talanta, 2010, 81(3): 805-812.

[11] M. Zečević, L. Živanović, S. Agatonovic-Kustrin, et al., The use of a response surface methodology on HPLC analysis of methyldopa, amiloride and hydrochlorothiazide in tablets. Journal of pharmaceutical and biomedical analysis, 2001, 24(5): 1019-1025.

[12] G.L. Munion, J.F. Seaton, T.S. Harrison, HPLC for urinary catecholamines and metanephrines with alphamethyldopa. Journal of Surgical Research, 1983, 35(6): 507-514.

[13] M. Doležalová, M. Tkaczyková, Direct high-performance liquid chromatographic determination of the enantiomeric purity of levodopa and methyldopa: comparison with pharmacopoeial polarimetric methods. Journal of pharmaceutical and biomedical analysis, 1999, 19(3): 555-567.

[14] M. Fouladgar, S. Ahmadzadeh, Application of a nanostructured sensor based on $\mathrm{NiO}$ nanoparticles modified carbon paste electrode for determination of methyldopa in the presence of folic acid. Applied Surface Science, 2016, 379: 150-155.

[15] L.F. Garcia, C.E.P. Cunha, E.K.G. Moreno, et al., Nanostructured $\mathrm{TiO}_{2}$ Carbon Paste Based Sensor for Determination of Methyldopa. Pharmaceuticals, 2018, 11(4): 99-108.

[16] Z. Talebpour, S. Haghgoo, M. Shamsipur, $1 \mathrm{H}$ nuclear magnetic resonance spectroscopy analysis for simultaneous determination of levodopa, carbidopa and methyldopa in human serum and pharmaceutical formulations. Analytica chimica acta, 2004, 506(1): 97104.

[17] M.I.H. Al Majidi, R. El-Shaheny, Y. El-Shabrawy, et al., Screening and greenness profiling of oxidative-coupling and electrophilic aromatic substitution reactions for determination of three phenolic drugs. Microchemical Journal, 2019, 149: 104051.

[18] R. Kimbahune, K. Sunil, P. Kabra, et al., Spectrophotometric simultaneous analysis of Ambroxol hydrochloride, Guaifenesin and Terbutaline sulphate in liquid dosage form (syrup). International Journal of Pharmaceutical Sciences Review and Research, 2011, 8(2): 24-28.

[19] M.A. Omar, K.M. Badr El-Din, H. Salem, et al., Spectrophotometric and spectrofluorimetric methods for determination of certain biologically active phenolic drugs in their bulk powders and different pharmaceutical formulations. Spectrochimica Acta Part A: Molecular and Biomolecular Spectroscopy, 2018, 192: 108-116.

[20] H.A. Hashem, M.S. Elmasry, W.E. Hassan, et al., Spectrophotometric and Stability-Indicating HighPerformance Liquid Chromatographic Determinations of
Terbutaline Sulfate. Journal of AOAC International, 2012, 95(5): 1412-1417.

[21] R. Karthick, J. Kavitha, and K. Lakshmi, Quantification of Terbutaline Sulphate in Pharmaceutical Formulation by UV Spectrophotometric aided Multivariate Calibration Technique. Research journal of Pharmacy and Technology, 2020, 13(2): 767-773.

[22] N. Theia'a, M.Y. Dhamra, and T.S. Al-Ghabsha, Spectrofluorimetric Determination of Tetracycline and Terbutaline Sulphate in its Pure and Dosage Forms Using Eosin y Reagent. European Chemical Bulletin, 2017, 6(8): 336-342.

[23] F.S. Felix, D. Daniel, J.R. Matos, et al., Fast analysis of terbutaline in pharmaceuticals using multi-walled nanotubes modified electrodes from recordable compact disc. Analytica chimica acta, 2016, 928: 32-38.

[24] W. Xu, R. Lei, W. Cao, et al., Voltammetric Method Using Multi-Walled Carbon Nanotubes Modified Glassy Carbon Electrode for the Determination of Terbutaline Sulfate in Pork Sample. Journal of Analytical Sciences, Methods and Instrumentation, 2013, 3(02): 75-79.

[25] M. Faiyazuddin, A. Rauf, N. Ahmad, et al., A validated HPTLC method for determination of terbutaline sulfate in biological samples: Application to pharmacokinetic study. Saudi Pharmaceutical Journal, 2011, 19(3): 185-191.

[26] H.J. Leis, H. Gleispach, V. Nitsche, et al., Quantitative determination of terbutaline and orciprenaline in human plasma by gas chromatography/negative ion chemical ionization/mass spectrometry. Biomedical \& Environmental Mass Spectrometry, 1990, 19(6): 382-386.

[27] M. Faiyazuddin, N. Ahmad, Z. Iqbal, et al., Development and Validation of UHPLC/ESI-Q-TOF-MS Method for Terbutaline Estimations in Experimental Rodents: Stability Effects and Plasma Pharmacokinetics. Current Pharmaceutical Analysis, 2012, 8(2): 189-195.

[28] K. Palur, B. Koganti, S.C. Archakam, Chemometricassisted RP-HPLC method for the simultaneous determination of ambroxol hydrochloride, terbutaline sulfate, and guaiphenesin in combined dosage form. Journal of Applied Pharmaceutical Science, 2019, 9(09): 092-097.

[29] A. Porel, S. Haty, and A. Kundu, Stability-indicating HPLC method for simultaneous determination of terbutaline sulphate, bromhexine hydrochloride and guaifenesin. Indian journal of pharmaceutical sciences, 2011, 73(1): 46-56.

[30] S. Cui, J. Liu, X. Hu, et al., Enantioseparation of terbutaline by online concentration capillary electrophoresis coupling with partial filling technique. Journal of Analytical Chemistry, 2015, 70(1): 81-86.

[31] K. Alaqad, T.A. Saleh, Gold and silver nanoparticles: synthesis methods, characterization routes and applications towards drugs. Journal of Environmental \& Analytical Toxicology, 2016, 6(4): 1-10.

[32] E. Gharibshahi, E. Saion, Quantum mechanical calculation of optical absorption of silver and gold nanoparticles by density functional theory. Physics International, 2010, 1(1): 57-64.

[33] M.H. Nezhad, J. Tashkhourian, and J. Khodaveisi, Sensitive spectrophotometric detection of dopamine, levodopa and adrenaline using surface plasmon resonance band of silver nanoparticles. Journal of the Iranian Chemical Society, 2010, 7(2): S83-S91.

[34] S. Durmazel, A.e. Üzer, B. Erbil, et al., Silver Nanoparticle Formation-Based Colorimetric Determination of Reducing Sugars in Food Extracts via Tollens’ Reagent. ACS Omega, 2019, 4(4): 7596-7604.

[35] M. Amjadi, T. Sodouri, A surface plasmon resonancebased method for detection and determination of cannabinoids using silver nanoparticles. Journal of 
Applied Spectroscopy, 2014, 81(2): 232-237.

[36] M.M. Ayad, H.E. Abdellatef, M.M. Hosny, et al., Determination of etilefrine hydrochloride, fenoterol hydrobromide, salbutamol sulphate and estradiol valerate using surface plasmon resonance band of silver nanoparticles. International Journal of Pharmacy and Pharmaceutical Sciences, 2015, 7(5): 327-333.

[37] F. Bamdad, F. Khorram, M. Samet, et al., Spectrophotometric determination of L-cysteine by using polyvinylpyrrolidone-stabilized silver nanoparticles in the presence of barium ions. Spectrochimica Acta Part A: Molecular and Biomolecular Spectroscopy, 2016, 161: 52-57.

[38] W. El-Alfy, O.A. Ismaiel, M.Y. El-Mammli, et al., Application of Silver Nanoparticles for the Spectrophotometric Determination of Cefdinir and Cefepime $\mathrm{HCl}$ in Pharmaceutical Preparations and Human Urine Samples. Nano Biomedicine and Engineering, 2019, 11(4): 381-390.

[39] R.E. Saraya, M. Elhenawee, and H. Saleh, Silver nanoparticles synthesis for sensitive spectrophotometric determination of sofosbuvir, lamivudine, and ritonavir in pure forms and pharmaceutical dosage forms. Journal of AOAC International, 2020, 103(1): 140-147.

[40] Z.A. Alothman, N. Bukhari, S. Haider, et al., Spectrofluorimetric determination of fexofenadine hydrochloride in pharmaceutical preparation using silver nanoparticles. Arabian journal of chemistry, 2010, 3(4): 251-255.

[41] B. Habibi, M. Jahanbakhshi, Silver nanoparticles/multi walled carbon nanotubes nanocomposite modified electrode: Voltammetric determination of clonazepam.
Electrochimica Acta, 2014, 118: 10-17.

[42] S. Han, X. Li, and B. Wei, Silver nanoparticle enhanced chemiluminescence method for the determination of nitrazepam. Analytical Sciences, 2014, 30(4): 495-500.

[43] B. Haghighi, S. Bozorgzadeh, Flow injection chemiluminescence determination of isoniazid using luminol and silver nanoparticles. Microchemical Journal, 2010, 95(2): 192-197.

[44] X.F. Zhang, Z.G. Liu, W. Shen, et al., Silver nanoparticles: synthesis, characterization, properties, applications, and therapeutic approaches. International journal of molecular sciences, 2016, 17(9): 1501-1534.

[45] G. Schmid, Clusters and colloids: from theory to applications, John Wiley \& Sons, Weinheim, New York: VCH Publishers, 1994

[46] K.M. Koczkur, S. Mourdikoudis, L. Polavarapu, et al., Polyvinylpyrrolidone (PVP) in nanoparticle synthesis. Dalton Transactions, 2015, 44(41): 17883-17905.

[47] ICH Harmonised Tripartite Guideline, Validation of analytical procedures: text and methodology Q2 (R1), Current Step 4 Version, Parent Guidelines on Methodology, International conference on harmonization, Geneva, Switzerland, incorporated in November 2005.

Copyright $₫$ Magda Mohamed Ayad, Mervat Mohamed Hosny, and Youstina Mekhail Metias. This is an open-access article distributed under the terms of the Creative Commons Attribution License, which permits unrestricted use, distribution, and reproduction in any medium, provided the original author and source are credited. 